Short Communication

\title{
Numerical Study on the Water Transport Through the Membrane of Proton Exchange Membrane Fuel Cells
}

\author{
Shian Li, Rongqiang Wei, Qiuwan Shen*, Guogang Yang* \\ Marine Engineering College, Dalian Maritime University, China. \\ *E-mail: shenqiuwan@dlmu.edu.cn and yanggg@dlmu.edu.cn
}

doi: $10.20964 / 2020.08 .49$

Received: 8 April 2020 / Accepted: 24 May 2020 / Published: 10 July 2020

\begin{abstract}
A two-dimensional mathematical model is developed to study the water transport through the membrane. The transport processes include the electro-osmotic drag process and back diffusion process. And a nonequilibrium water sorption model is employed to describe the water absorption process in the catalyst layers. The effect of absorption coefficient of water on transport characteristics are comprehensively investigated. It is concluded that the cell performance and transport phenomena inside fuel cells are significantly affected by the water absorption process. The obtained polarization curves are presented and compared. The distributions of temperature, liquid water saturation, water content and local current density at cell voltages $0.6 \mathrm{~V}$ and $0.3 \mathrm{~V}$ are also comprehensively analyzed.
\end{abstract}

Keywords: Proton exchange membrane fuel cells, Absorption process, Cell performance, Transport characteristics

\section{FULL TEXT}

(C) 2020 The Authors. Published by ESG (www.electrochemsci.org). This article is an open access article distributed under the terms and conditions of the Creative Commons Attribution license (http://creativecommons.org/licenses/by/4.0/). 